\title{
乾シイタケの用途別代替に関する実証分析
}

松本 典子 (鳥取大学大学院)
古塚 秀夫 (鳥取大学農学部)
松田 敏信 (鳥取大学農学部)

\section{Empirical Analysis of the Demand for Dry Shiitake Mushrooms on the basis of their Usage}

\author{
Noriko Matsumoto (Graduate School of Agriculture, Tottori University) \\ Hideo Furutsuka (Faculty of Agriculture, Tottori University) \\ Toshinobu Matsuda (Faculty of Agriculture, Tottori University)
}

In this paper, we analyzed the demand for dry shiitake mushrooms on the basis of their usage. Following the analysis, we can state the following.

1. The Japanese dry shiitake mushroom and Chinese dry shiitake mushroom are found to be neither substitutional nor complementary, probably because their usage patterns are different.

2. Japanese dry shiitake mushrooms meant for

\section{1. はじめに}

近年，農産物の残留農薬問題や産地偽装の問題な どによって，中国産乾シイタケの輸入量は減少して いる. しかし，1985 年以降の円高によって中国産 乾シイタケの輸入量が急増した影響を大きく受け て，現在に拧いても国内価格は低迷し，また，国内 生産量は減少している。中国産乾シイタケは主に業 務用に利用されているが，中国産乾シイタケを輸入 する理由として，価格が安いことの他に，一定規格 のものを量的に確保することが可能であることがあ る. このことは, 国内生産量の減少に伴って, 規格 によっては量的確保が難しくなっていることと表裏 一体の関係にある。

そこで，本研究では，乾シイタケに関して次の 2 つについて代替関係と補完関係を明らかにする。す なわち，(1)日本産と中国産との間と，(2)日本産の各 用途に打ける規格間についてである. 分析データは, 全農入札会データと, 中国からの輸入データである. こ机らのデータを用いた理由であるが，国内生産量 に占める全農入札会シェアが 12.1\%（2007 年）と domestic consumption and those meant for export are sometimes used substitutionally and sometimes complementarily. When the mushrooms had similar forms, colors, and gloss were harvested around the same time and in particular, were more or less similarly priced, they were used substitutionally. Further, when both the sizes and the prices of the mushrooms were similar, they were used complementarily.

高いことと，日本の乾シイタケ輸入量に占める中国 産のシェアが 96.4\%（2007 年）と高いためである. したがって，全農入札会の乾シイタケを日本産とみ なして, 中国産との関係を需要分析で明らかにする。 計測期間は 1994 年 5 月から 2007 年 4 月の 13 年間で ある。分析対象の規格は，全農規格 25 のらち各用 途に打いて取扱量が多い上位 5 規格のらちで，デー タが揃っている 13 規格である。なお，ここでいら 用途とは，家庭用，業務用，輸出用である。また， 全農規格の構成要素は，大きさ，形状，色沢，採取 時期である。

\section{2. 分析方法}

\section{（1）予備的考察}

第 1 に，シイタケの計量分析に関する既往の研究 成果について検討する。第 2 亿，需要分析に移る前 に，乾シイタヶの取扱量や価格について時系列分析 を行う。この計測期間は，1988 年 1 月から 2007 年 4 月までである.とくに，季節変動については EPA 法を用いて分析している. 


\section{（2）需要分析モデルの設定}

最小二乗法による回帰曲線を用いて需要分析を 行う. 普通最小二乗法では, 誤差項に自己相関が ある場合に D.W. 值による系列相関の検定は偏りを 持つため一般化最小二乗法を使用している。 また， パラメーターに異常值が推定されるのを防ぐため に, 取扱量, 価格, 消費支出は対前月階差（例光ば, $\left.\Delta \ln Q_{\mathrm{mt}}=\ln \mathrm{Q}_{\mathrm{mt}}-\ln \mathrm{Q}_{\mathrm{mt}-1}\right)$ をとっている. 用途別代替 関係と補完関係の分析については，t検定の結果， $5 \%$ 以上の水準で有意を示す規格について考察す

る. 計測モデルは以下のと招りである.

〈需要分析モデル〉

$$
\begin{aligned}
\Delta \ln Q_{m t} & =a_{0}+\sum_{m=1}^{M} a_{m} \Delta \ln P_{m t}+a_{m+1} \Delta \ln Y_{t} \\
& +\sum_{n=1}^{11} b_{n} D_{n}+u_{t}
\end{aligned}
$$

$\mathrm{Q}_{\mathrm{mt}}$ : 規格 $\mathrm{m}$ の $\mathrm{t}$ 期の取扱量 $(\mathrm{t}), \mathrm{P}_{\mathrm{mt}}$ : 規格 $\mathrm{m}$ の $\mathrm{t}$ 期 の $1 \mathrm{~kg}$ 当たり価格（円 $/ \mathrm{kg}$ ), $\mathrm{Y}_{\mathrm{t}}$ : $\mathrm{t}$ 期の 1 世帯当た り消費支出 $($ 円 $), \mathrm{D}_{\mathrm{n}}$ : 月別ダミ一変数 $(\mathrm{n}=1 \sim 11)$, $u_{\mathrm{t}}$ : $\mathrm{t}$ 期の誤差項, $\mathrm{a}_{0} \sim \mathrm{a}_{\mathrm{m}+1}, \mathrm{~b}_{\mathrm{n}}$ : 推定すべきパラメーター $(\mathrm{n}=1 \sim 11)$

注：計測モデルの $\mathrm{m}$ には全農規格の他に「中国産」 が 1 つの規格として含まれる.

出所 : 全農入札会資料（1994 年～2007 年), 財務 省『貿易統計』(1994 年～ 2007 年), 総務省 統計局『家計調查年報』(1994 年～ 2007 年)

\section{3. 計測結果及び考察}

\section{（1）予備的考察}

\section{1）既往の研究成果}

乾シイタケの計量分析として西井氏の文献 [2] がある. 西井氏は計量経済学的手法を用いて, シイ タケの生産・流通・消費過程の総括的把握に努めて いる. その結果, 構造方程式モデルによって乾シイ タケについては次の 3 点を明らかにしている. すな わち，(1)経営規模の維持期待が伏込み本数に影響す ること, (2)価格変動が発生操作へ影響してほだ木単 位当たり生産量に作用すること, (3)国内消費量の卸 売価格に対する弾力性は小さく, 非弾力的であるが, 輸出量の価格弾力性は大きく, 贅沢財的性格が強い ことである. 乾シイタケの計量分析に関する研究成 果は西井氏のものだけである. この成果の他に生シ
イタケの計量分析の成果として大浦氏の文献 [3] がある，大浦氏は，生シイタケの日本産と中国産に ついて次の 3 点を明らかにしている。すすおち，(1) 中国産生シイタケの需要は東京市場と大阪市場では 代替関係に大きな違いはないこと, (2)日本産生シイ タケの需要は大阪市場より東京市場のほうが価格に 対して弾力的であること, (3)中国産生シイタケは日 本産の代替財であることである.

西井氏の分析対象は 1965 年から 1977 年であり, 自由度が小さい。また, 対象期間が中国産乾シイタ ケが大きな市場シェアを占めるようになった現在と は乾シイタケをめぐる情勢が大きく異なっている. 大浦氏の分析対象は近年であるが，モデルは普通最 小二乗法であり䛊差項に系列相関がみられる。これ ら 2 つの研究成果を踏ま兄て, 本研究では, データ は対前月階差をとり，一般化最小二乗法を用いたも デルによって分析を行っている.

\section{2) 時系列分析}

第 1 亿，長期的な傾向である. その 1 として, 全 農入札会データによって国内の動向をみると, 図 1 のようになる。乾シイタケは自然環境下で生産され るために取扱量と入札価格は年次変動が大きい. ᄂ かし, 取扱量と入札価格は横ばい傾向を示している. 分析期間に拈ける年平均取扱量は $552 \mathrm{t}$ であり, 平 均入札価格は約 3,601 円 $/ \mathrm{kg}$ である. その 2 として, 中国産の動向をみると, 図 2 のようになる。輸入量 は 1991 年から 1994 年まで急増し, 1997 年の 9,267 t をピークに減少傾向にある。輸入価格は 1990 年の 1,657 円 $/ \mathrm{kg}$ をピークに低下傾向である.

第 2 に, 季節変動である. 季節変動の有無を確認 するために，分散分析を行っている．分散分析の結 果，分析データはすべて F 検定に扎いて $1 \%$ 水準で 有意である。そこで，EPA 法によって季節指数を 計測している。 その 1 として，全農入札会によって 国内の動向をみるが，用途別に代表的な規格に関し て, 取扱量と入札価格の季節指数を図示すると図 3 のよらになる。取扱量はすべての用途に拈いて冬に 少なく，8月を除く夏と秋が多い，季節指数の標準 偏差を表 1 と表 2 亿示す。家庭用と業務用について は標準偏差が小さくなり, 季節変動が小さくなって いることがわかる。しかし, 輸出用は変動が大きく, このような傾向はない，入札価格では，家庭用と業 務用は冬と春に安く，夏から秋にかけて高い。輸出 


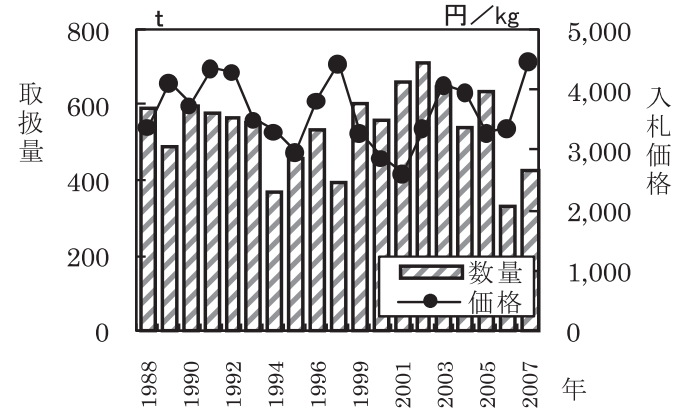

図 1. 全農入札会の取扱量と入札価格

出所 : 全農入札会資料（1988 年〜 2007 年）

注 : 1) 数量は全農総取扱量である.

2) 1998 年のデータはない.

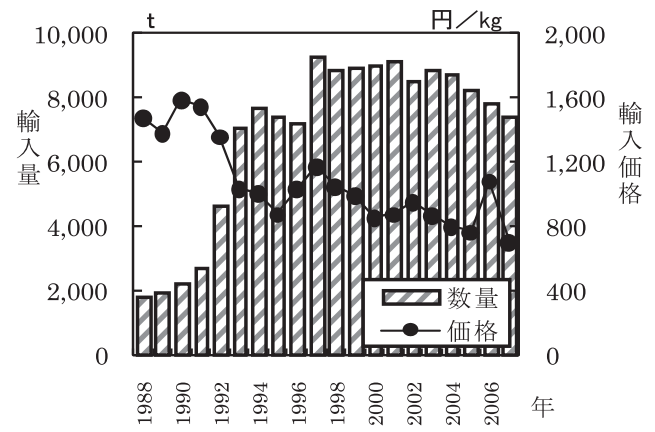

図 2. 中国産の輸入量と輸入価格

出所 : 財務省『貿易統計』(1988 年〜 2007 年)

注 : 2007 年のデータは 4 月までである.

用は変動が激しいが，近年（2005 年）家庭用や業 務用と同じような季節変動を示している. 季節指数 の標準偏差は，家庭用は小さくなっているが，業務 用や輸出用は変動が大きい. その 2 として, 中国産 の輸入量と輸入価格であるが, 図 3 のようになる. 輸入量は冬から春にかけて多く, 夏は少ない。輸入 価格は夏が安く，低価格で冬が高かったが，近年は 夏が高く, 冬が安くなっている. 季節指数の標準偏 差をみると，輸入量，輸入価格ともに小さくなり， 両者の季節変動は小さくなっている.

\section{(2) 需要分析}

計測結果を表 3 に示す. 第 1 に, 自己価格弾力性 と所得弾力性についてみる. その 1 として, 自己価 格弾力性は，輸出用の並どんこで有意な值であるが， それ以外の規格と中国産に拈いては有意な結果は得 られていない，これは，乾シイタヶでは自己価格が 需要に影響していないためである. 所得弾力性は,
表 1. 全農取扱量と輸入量に関する季節指数の標準 偏差

\begin{tabular}{l|c|c|c|c}
\hline \hline & 1990 年 & 1995 年 & 2000 年 & 2005 年 \\
\hline 家庭用 (特中並) & - & 0.54 & 0.43 & 0.36 \\
\hline 業務用 (加工大) & 0.35 & 0.32 & 0.54 & 0.37 \\
\hline 輸出用 (並どんこ) & 0.75 & 0.54 & 0.74 & 0.65 \\
\hline 輸入量 & 0.68 & 0.54 & 0.35 & 0.22 \\
\hline
\end{tabular}

出所 : 全農入札会資料（1990 年～ 2005 年), 財務省『貿 易統計』(1990 年〜 2005 年)

注 : 家庭用規格の 1990 年のデータはない.

表 2. 入札価格と輸入価格に関する季節指数の標準 偏差

\begin{tabular}{l|c|c|c|c}
\hline \hline & 1990 年 & 1995 年 & 2000 年 & 2005 年 \\
\hline 家庭用 (特中並) & - & 0.05 & 0.05 & 0.03 \\
\hline 業務用 (加工大) & 0.07 & 0.05 & 0.09 & 0.06 \\
\hline 輸出用 (並どんこ) & 0.04 & 0.03 & 0.06 & 0.07 \\
\hline 輸入価格 & 0.05 & 0.04 & 0.03 & 0.01 \\
\hline
\end{tabular}

出所：全農入札会資料（1990年～2005 年), 財務省『貿 易統計』(1990 年〜 2005 年)

注 : 家庭用規格の 1990 年のデータはない。

家庭用の特小厚, 輸出用の特小上厚, 特小厚, 特下厚, 並どんこ，小どんこで有意である．この結果，以下 のことがわかる．すなわち，(1)家庭用では，特に特 小厚で大きな值となって拈り, 所得が増加すると, 特小厚を購入することが分かる. (2)輸出用の所得弾 力性が有意な值である. これは，もともと高価な輸 出用が輸出の減少によって国内仕向けとなり, 所得 増加によってその購入量が増加しているためだと考 えられる. (3) $\mathrm{t}$ 検定では 5\%水準で有意ではないが家 庭用之業務用に括いて, 中国産は所得弾力性がマイ ナスである. すなわち, 下級財的な性格をもっている.

第 2 に，代替関係である，その 1 として，日本産 と中国産の関係である. 中国産と輸出用の並どんこ の関係については, 両者は直接代替関係にはないが, 香港市場に打ける中国産のシェアが拡大したことに よって日本の輸出量が減少していることが中国産と 輸出用並どんこが代替関係にあるといら計測結果の 原因と考兄られ、したがって，日本産と中国産の 代替関係はみられない.すなわち，これは日本産と 中国産では棲み分けがされていることを意味してい 

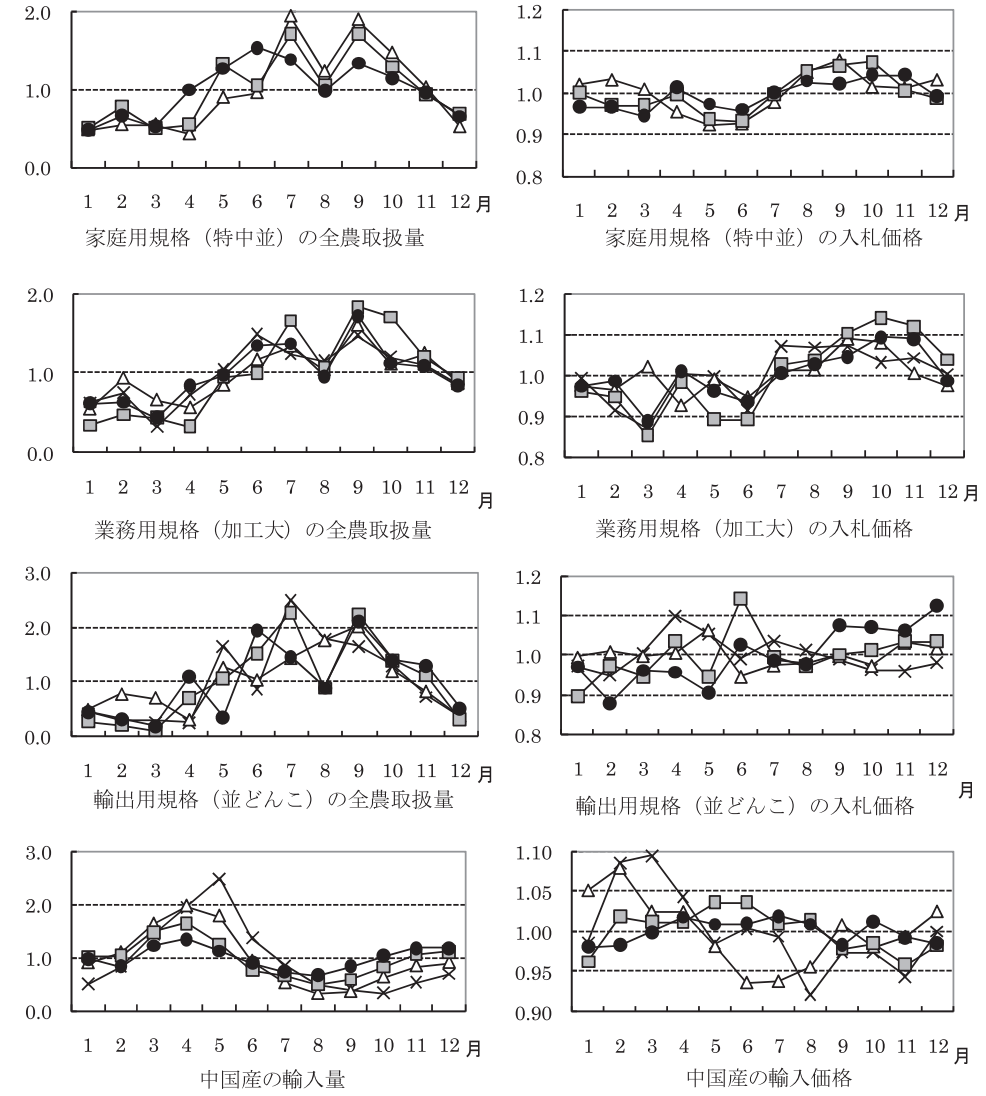

× 1990年 $\triangle 1995$ 年 $\square-2000$ 年 $\multimap 2005$ 年

図 3. 用途別および中国産の季節指数（EPA 法）

出所：全農入札会資料（1988 年～ 2007 年)，財務省『貿易統計』(1988 年〜 2007 年)

注 : 家庭用規格の 1990 年のデータはない.

る.その 2 として，用途別代替関係である．業務用 の加工大が加工小の代替財である. 加工大は主とし て学校給食などの集団給食に用いられる. 加工小は 家庭用一般小袋等に用いられる。つまり, 両者の利 用が異なっている. しかし, 加工大と加工小は価格 が相対的に安いために，安価な規格間で代替関係が 存在している，輸出用の並どんこと小どんこは，互 いに代替関係にある. 小どんこの価格が並どんこよ り安いが，小どんこの取扱量が少ないため，並どん こが小どんこの代替財となっている.

代替関係では「大きさ」を除く規格，すなわち， 形状，色沢，採取時期が同じ (並どんこと小どんこ では，それぞれ順に，厚肉・丸型，淡黄色，5分〜 6 分開き ${ }^{1)}$, 加工大と加工小では, 同じくバレ・変形,
茶褐色, 全開以上 ) で, しかも, 価格格差が相対的 に小さい規格間に打いて代替関係が存在している.

第 3 に, 補完関係である. その 1 として, 日本産 と中国産の関係である. 日本産と中国産の補完関係 は夕られない.すなわち，これは代替関係と同様に 棲み分けがされていることを意味している．その 2 として，用途別補完関係である，家庭用では，特小 上厚が特小並の, 特小厚が特小並の, 輸出用では, 特小上厚が小どんこの，小どんこが特小厚の補完財 である。乾シイタケでは入札に参加した卸売問屋の 段階で，数種類の規格を混合して販売する.

補完関係では,「大きさ」 $(3 \mathrm{~cm} \sim 4.5 \mathrm{~cm})$ と「色沢」 (濃黄色・薄茶色) ${ }^{2)}$ が同じで，しかも，価格格差 が相対的に小さい規格間で補完関係になっている. 
表 3. 需要分析モデルの計測結果

(1)家庭用規格

\begin{tabular}{|c|c|c|c|c|c|c|c|c|}
\hline $\mathrm{Qm}$ & 特小厚 & 特小上厚 & 特中並 & 特小並 & 中国産 & 所得弾力性 & $\begin{array}{l}\text { 自由度調整済 } \\
\text { 又決定係数 }\end{array}$ & D.W. 值 \\
\hline 特小厚 & $\begin{array}{c}0.570 \\
(0.853) \\
\end{array}$ & $\begin{array}{c}-0.245 \\
(-0.356)\end{array}$ & $\begin{array}{c}-0.410 \\
(-0.580)\end{array}$ & $\begin{array}{l}-1.131^{* *} \\
(-2.165)\end{array}$ & $\begin{array}{c}0.322 \\
(0.483) \\
\end{array}$ & $\begin{array}{l}3.237^{* *} \\
(2.207)\end{array}$ & 0.470 & 2.215 \\
\hline 特小上厚 & $\begin{array}{c}-0.142 \\
(-0.207)\end{array}$ & $\begin{array}{c}-0.253 \\
(-0.357)\end{array}$ & $\begin{array}{c}1.434^{*} \\
(1.942) \\
\end{array}$ & $\begin{array}{l}-1.233^{* * *} \\
(-2.293)\end{array}$ & $\begin{array}{c}-0.250 \\
(-0.355)\end{array}$ & $\begin{array}{c}1.867 \\
(1.243) \\
\end{array}$ & 0.461 & 2.235 \\
\hline 特中並 & $\begin{array}{l}-1.070^{*} \\
(-1.811)\end{array}$ & $\begin{array}{c}0.769 \\
(1.255)\end{array}$ & $\begin{array}{l}-0.048 \\
(-0.076)\end{array}$ & $\begin{array}{c}0.025 \\
(0.053)\end{array}$ & $\begin{array}{l}-0.306 \\
(-0.503)\end{array}$ & $\begin{array}{c}1.022 \\
(0.788)\end{array}$ & 0.444 & 2.197 \\
\hline 特小並 & $\begin{array}{c}-1.719 \\
(-1.322)\end{array}$ & $\begin{array}{c}0.161 \\
(0.211) \\
\end{array}$ & $\begin{array}{c}1.120 \\
(1.418)\end{array}$ & $\begin{array}{c}-0.150 \\
(-0.259)\end{array}$ & $\begin{array}{c}-0.132 \\
(-0.177)\end{array}$ & $\begin{array}{c}2.918^{*} \\
(1.796) \\
\end{array}$ & 0.413 & 2.146 \\
\hline 中国産 & $\begin{array}{c}0.374 \\
(1.502)\end{array}$ & $\begin{array}{c}-0.079 \\
(-0.299)\end{array}$ & $\begin{array}{c}-0.182 \\
(-0.646)\end{array}$ & $\begin{array}{c}-0.077 \\
(-0.389)\end{array}$ & $\begin{array}{c}-0.254 \\
(-0.907)\end{array}$ & $\begin{array}{l}-1.018^{*} \\
(-1.877)\end{array}$ & 0.578 & 1.968 \\
\hline
\end{tabular}

(2)業務用規格

\begin{tabular}{|c|c|c|c|c|c|c|c|c|}
\hline $\mathrm{Qm}$ & 加工大 & 特大並 & 加工小 & 特下厚 & 中国産 & 所得弾力性 & $\begin{array}{c}\text { 自由度調整済 } \\
\text { 又決定係数 }\end{array}$ & D.W. 值 \\
\hline 加工大 & $\begin{array}{c}0.216 \\
(0.447)\end{array}$ & $\begin{array}{c}-0.767 \\
(-1.343)\end{array}$ & $\begin{array}{c}0.549^{* * *} \\
(2.108)\end{array}$ & $\begin{array}{c}-0.203 \\
(-0.998)\end{array}$ & $\begin{array}{c}0.004 \\
(0.007)\end{array}$ & $\begin{array}{c}1.711 \\
(1.458)\end{array}$ & 0.536 & 2.202 \\
\hline 特大並 & $\begin{array}{c}-0.776 \\
(-1.555)\end{array}$ & $\begin{array}{c}0.232 \\
(0.393)\end{array}$ & $\begin{array}{c}0.882 \\
(0.347)\end{array}$ & $\begin{array}{c}-0.354 \\
(-1.678)\end{array}$ & $\begin{array}{c}-0.108 \\
(-0.192)\end{array}$ & $\begin{array}{c}1.716 \\
(1.432)\end{array}$ & 0.519 & 2.224 \\
\hline 加工小 & $\begin{array}{c}-0.522 \\
(-0.700)\end{array}$ & $\begin{array}{c}-0.461 \\
(-0.522)\end{array}$ & $\begin{array}{c}0.724^{*} \\
(1.832)\end{array}$ & $\begin{array}{c}-0.607^{*} \\
(-1.918)\end{array}$ & $\begin{array}{c}0.609 \\
(0.721) \\
\end{array}$ & $\begin{array}{c}1.562 \\
(0.878) \\
\end{array}$ & 0.363 & 2.211 \\
\hline 特下厚 & $\begin{array}{c}-0.296 \\
(-0.326)\end{array}$ & $\begin{array}{c}0.215 \\
(0.200)\end{array}$ & $\begin{array}{c}0.484 \\
(1.016)\end{array}$ & $\begin{array}{c}-0.297 \\
(-0.770)\end{array}$ & $\begin{array}{c}0.890 \\
(0.866)\end{array}$ & $\begin{array}{c}3.549 \\
(1.633)\end{array}$ & 0.263 & 2.298 \\
\hline 中国産 & $\begin{array}{c}0.139 \\
(0.581)\end{array}$ & $\begin{array}{c}-0.162 \\
(-0.574)\end{array}$ & $\begin{array}{c}-0.035 \\
(-0.297)\end{array}$ & $\begin{array}{c}0.053 \\
(0.512)\end{array}$ & $\begin{array}{c}-0.221 \\
(-0.792)\end{array}$ & $\begin{array}{c}-0.940^{*} \\
(-1.722)\end{array}$ & 0.571 & 1.992 \\
\hline
\end{tabular}

(3)輸出用規格

\begin{tabular}{|c|c|c|c|c|c|c|c|c|c|}
\hline $\mathrm{Qm}$ & 特小上厚 & 特小厚 & 特下厚 & 並どんこ & 小どんこ & 中国産 & 所得弾力性 & $\begin{array}{c}\text { 自由度調整済 } \\
\text { み決定係数 }\end{array}$ & D.W. 值 \\
\hline 特小上厚 & $\begin{array}{c}-0.286 \\
(-1.014) \\
\end{array}$ & $\begin{array}{c}-0.282 \\
(-0.734)\end{array}$ & $\begin{array}{c}-0.273^{*} \\
(-1.756)\end{array}$ & $\begin{array}{c}-0.146 \\
(-0.623)\end{array}$ & $\begin{array}{l}-0.206^{* *} \\
(-2.560)\end{array}$ & $\begin{array}{c}-0.321 \\
(-0.975)\end{array}$ & $\begin{array}{c}0.958^{* * * *} \\
(22.000) \\
\end{array}$ & 0.878 & 2.320 \\
\hline 特小厚 & $\begin{array}{l}-0.513^{*} \\
(-1.944)\end{array}$ & $\begin{array}{c}-0.428 \\
(-1.198)\end{array}$ & $\begin{array}{c}-0.061 \\
(-0.419)\end{array}$ & $\begin{array}{c}0.039 \\
(0.180)\end{array}$ & $\begin{array}{c}-0.483 \\
(-0.395)\end{array}$ & $\begin{array}{c}0.180 \\
(0.573)\end{array}$ & $\begin{array}{c}0.964^{* * * *} \\
(23.680)\end{array}$ & 0.892 & 2.209 \\
\hline 特下厚 & $\begin{array}{l}-1.033^{*} \\
(-1.907) \\
\end{array}$ & $\begin{array}{c}-0.130 \\
(-0.177)\end{array}$ & $\begin{array}{c}0.170 \\
(0.568) \\
\end{array}$ & $\begin{array}{c}0.532 \\
(1.184) \\
\end{array}$ & $\begin{array}{c}-0.219 \\
(-0.868)\end{array}$ & $\begin{array}{c}0.962 \\
(1.512) \\
\end{array}$ & $\begin{array}{c}1.165^{* * * *} \\
(13.930) \\
\end{array}$ & 0.711 & 2.329 \\
\hline 並どんこ & $\begin{array}{l}-0.742 \\
(-1.479)\end{array}$ & $\begin{array}{c}0.764 \\
(1.136)\end{array}$ & $\begin{array}{c}0.322 \\
(1.174)\end{array}$ & $\begin{array}{l}-2.166^{* * * *} \\
(-5.274)\end{array}$ & $\begin{array}{l}0.723^{* * * *} \\
(3.141)\end{array}$ & $\begin{array}{c}0.870 \\
(1.487)\end{array}$ & $\begin{array}{c}1.135^{* * * *} \\
(14.840)\end{array}$ & 0.791 & 2.199 \\
\hline 小どんこ & $\begin{array}{c}0.054 \\
(0.073)\end{array}$ & $\begin{array}{l}-1.977^{* * *} \\
(-1.983)\end{array}$ & $\begin{array}{c}-0.049 \\
(-0.121)\end{array}$ & $\begin{array}{l}1.197^{* * *} \\
(1.968)\end{array}$ & $\begin{array}{c}0.077 \\
(0.227)\end{array}$ & $\begin{array}{c}-0.146 \\
(-0.166)\end{array}$ & $\begin{array}{l}0.984^{* * * *} \\
(8.661)\end{array}$ & 0.548 & 2.203 \\
\hline 中国産 & $\begin{array}{c}0.197 \\
(0.910)\end{array}$ & $\begin{array}{c}-0.226 \\
(-0.788)\end{array}$ & $\begin{array}{c}-0.024 \\
(-0.200)\end{array}$ & $\begin{array}{l}0.490^{\text {w*** }} \\
(2.831)\end{array}$ & $\begin{array}{l}-0.001 \\
(-0.007)\end{array}$ & $\begin{array}{c}-0.293 \\
(-1.060)\end{array}$ & $\begin{array}{c}-0.032 \\
(-0.956)\end{array}$ & 0.587 & 1.962 \\
\hline
\end{tabular}

出所：全農入札会資料（1994 年～ 2007 年), 総務省統計局『家計調查年報』(1994 年～ 2007 年), 財務省『貿易統計』(1994 年〜 2007 年)

注 : 1)（）内はt- 值である.

2）“** は $\mathrm{t}$ 検定に打いて 1\%水準で有意を，"*は5\%水準で有意を，“は10\%水準で有意を示す.

3）D.W. 值はダービン・ワトソン值を表す. 
最後に，以上のことをとりまとめると，次の $2 つ$ になる，すなわち，その 1 として，日本産と中国産 との関係であるが，両者は棲及分计が行われている ために中国産が日本産へ与える影響は明確にはみら れない，その 2 として，用途別代替関係と補完関係 であるが，価格格差が小さく，外見上よく似た規格 間で両者の関係が存在している。ささらに，代替関係 にある財の方が, 補完関係にある財より規格の構成 要素のらちで, 共通している要素が多い.

\section{4. あとがき}

プラザ合意後, 中国産乾シイタケの輸入が急増し, 日本の消費量の半分以上を中国産が占めるように なっている. しかし, 今後, 経済成長が続けば, 中 国産は下級財であるために，輸入量は減少すると推 察される。また，前述のように日本に和任る乾シイ タケ生産量が減少して, 規格によっては量的確保が 難しくなっている.この対策として, 全農規格数 (25)
を減少させることが考兄られるが，今回の用途別代 替関係や補完関係で明らかにしたことがこの規格の 見直しに貢献するであろう。

注 1）小どんこの採取時期は， 5 分〜 7 分開きであり例 外である。

2）小ぞんこの色沢は淡黄色で例外である.

\section{参考文献}

[1]古塚秀夫「国際価格競争下に打忊る日本産乾 シイタケの販売戦略」、システム農学』, 第 16 巻 1 号 (2000 年), pp. 17-26.

[2] 西井一成「シイタケの生産・流通・消費構造 の計量経済学的分析」, 『農林業問題研究』, 第 18 巻 1 号 (1982 年), pp. 26-33.

[3] 大浦明子・古塚秀夫「生シイタケの需要に関 する計量分析」, 『農林業問題研究』, 第 37 巻 第 4 号 (2002 年), pp. 365-368.

[4]谷口憲治『シイタケの経済学』, 農林統計協会, 1989 年. 